\title{
STUDI DESKRIPTIF TENTANG GAYA KEPEMIMPINAN MANAGER OPERASIONAL PT. BANK "X" CABANG PAMANUKAN
}

\author{
Lisa Widawati, Wilma Wirachmaria Sari
}

1_wido@yahoo.co.id

\begin{abstract}
Abstrak
Penelitian ini bertujuan mendeskripsikan gaya kepemimpinan unit operasional PT Bank $X$ dengan menggunakan angket persepsi terhadap gaya kepemimpinan mengacu teori Hersey \& Blanchard. Dari 22 partisipan diperoleh hasil 40,91\% karyawan memiliki kematangan tinggi (M4) mempersepsi gaya kepemimpinan atasan sebagai gaya telling. 27,27\% karyawan memiliki kematangan sedang ke tinggi (M3) yang mempersepsi gaya kepemimpinan atasan sebagai gaya selling, sedangkan 18,18\% karyawan yang memiliki kematangan rendah ke sedang (M2) mempersepsi gaya kepemimpinan atasan sebagai gaya participating. Terakhir 13,64\% karyawan yang memiliki kematangan rendah (M1) mempersepsi gaya kepemimpinan atasan sebagai gaya delegating.
\end{abstract}

Kata kunci : Persepsi, Gaya Kepemimpinan dan Kematangan Bawahan

Abstract

This research aims to describe leadership style on operational unit of PT Bank X using perception survey toward leadership style based on Hersey and Blancard thery. Having 22 participants, the results shows that 40,91\% employee give perception of their leader having telling style. Meanwhile, 27,27\% participants give perception about their leaer having selling style. In addition, 18,18\% participants have participating style leader and the last 13,64\% leadership perceived as having delegating style.

Keywords : Perception, leadership style

\section{PENDAHULUAN}

Industri perbankan telah mengalami perubahan besar dalam beberapa tahun terakhir. Industri ini menjadi lebih kompetitif karena deregulasi peraturan memberi peluang bagi pemilik modal untuk mengembangkan bisnisnya di dunia perbankan dengan berbagai varian produknya yang juga makin berkembang. Kegiatan menghimpun dan menyalurkan dana merupakan kegiatan pokok bank sedangkan memberikan jasa bank lainnya hanya kegiatan pendukung.

Demikian halnya dengan PT. Bank "X" cabang Pamanukan, sebagai bank milik pemerintah dalam menjalankan usahanya, senantiasa berusaha untuk mendorong para karyawannya dapat memberikan kualitas kerja yang terbaik, sehingga tujuan perusahaan dapat tercapai.

Keberhasilan dan efektifitas pencapaian tujuan perusahaan dapat dilihat dari kinerja yang ditunjukkan melalui capaian 
target yang diharapkan. Capaian target perusahaan tidak akan terlepas dari peran SDM yang memegang peranan penting dalam menjalankan roda organisasi. Fakta yang terjadi, target pendapatan di PT.Bank "X" cabang Pamanukan pada tahun 20122013 masih belum memenuhi goal setting yang ditentukan pihak manajemen kantor pusat.

Sebagai suatu bank pemerintah yang saat ini telah berkembang pesat, sistem kebijakan pemberian penghargaan berupa, gaji, tunjangan serta fasilitas lain telah diberikan dan diasumsikan telah sejajar dengan bank-bank pemerintah yang terkemuka. Demikian pula fasilitas pendidikan den pengembangan karyawan senantiasa diberikan secara berkesinambungan. Secara teoretis berbagai faktor dapat menjadi sumber mengapa target perusahaan tidak tercapai, diantaranya berasal dari kebijakan manajemen yang terlalu tinggi, faktor ability karyawan, faktor kepemimpinan, faktor ketidakpuasan serta faktor-faktor lain.

Fenomena yang terjadi di PT. Bank "X" Cabang Pamanukan diperoleh gambaran bahwa karyawan merasa pimpinan, dalam hal ini Manajer Operasional masih kurang dapat menjalankan perannya dengan maksimal. Dalam mengelola bawahan, pimpinan mengabaikan berbagai hal yang terkait dengan kondisi bawahan. Penetapan target kerja dilakukan dan ditekankan pada seluruh unsur bawahan dengan cara "empowerment" yang sama.

Pendelegasian tugas yang sepenuhnya diberikan pada karyawan pun dirasakan kurang mendukung hasil kerja karena kebijakan penugasan tidak mempertimbangkan kondisi dan kemampuan bawahan. Acuan lama kerja lebih digunakan oleh pimpinan dalam menetapkan kebijakan penugasan kerja sehingga penugasan kepada karyawan lama diasumsikan oleh pimpinan akan memberikan jaminan penyelesaian tugas lebih baik dibandingkan karyawan baru. Pandangan ini tidak sepenuhnya salah karena pimpinan memiliki alasan yang rasional bahwa karyawan dengan pengalaman yang lebih lama akan memiliki kemampuan yang lebih dibanding karyawan baru. Anggapan pimpinan tersebut berbanding terbalik dengan apa yang dirasakan oleh karyawan baru. Dengan bekal pelatihan serta pengalaman yang dimiliki, karyawan merasa bahwa mereka siap dalam mengerjakan setiap tugas yang seharusnya menjadi tugas mereka.

Konsep teori kepemimpinan situasional yang dikemukakan oleh Herzey \& Blanchard (Robin, 2007:367) menjelaskan bahwa "a leadership contingency theory that focuses on followers readiness/maturity". Inti dari teori kepemimpinan situational adalah teori kontingensi yang memusatkan perhatian pada pengikutnya. Kepemimpinan yang berhasil, dicapai dengan memilih perilaku kepemimpinan yang tepat dan mempertimbangkan tingkat kesiapan dan kedewasaan para pengikutnya. Implementasi dari konsep teori ini adalah bahwa ciri kesiapan dan kedewasaan serta kemampuan yang dimiliki oleh bawahan akan berbeda sehingga memerlukan penanganan yang berbeda pula. Penanganan yang tepat dengan mempertimbangkan kondisi bawahan akan mampu mengoptimalkan kinerja bawahan sehingga menghasilkan produktivitas kerja yang diharapkan.

Beranjak dari fenomena yang terjadi, peneliti tertarik untuk melakukan penelitian dengan judul "Studi Deskriptif Tentang Gaya Kepemimpinan atasan yang dipersepsi Karyawan Bagian Operasional di PT. Bank " $X$ ” $T B K$ Cabang Pamanukan"

Adapun tujuan penelitian ini diarahkan untuk mendapatkan gambaran bagaimana gaya kepemimpinan situasional pimpinan pada unit operasional dan bagaimana kematangan bawahan serta apakah terdapat kesesuaian. Dengan tujuan tersebut diharapkan akan mendapatkan hasil berupa gambaran mengenai bagaimana gaya kepemimpinan manajer opera- 
sional yang dipersepsi oleh bawahan serta gambaran kematangan bawahan disertai kesesuaiannya. Diharapkan hasil yang diperoleh dapat memberikan manfaat dalam hal saran ataupun intervensi bagaimana mengembangkan kepemimpinan yang dimiliki yang mengkaitkan dengan kondisi bawahan.

Permasalahan kepemimpinan situasional merupakan suatu hal yang menarik untuk dikaji secara mendalam, meski saat ini pendekatan kepemimpinan transformasional inpirasional berkembang menjadi suatu pendekatan baru. Kepemimpinan dalam suatu organisasi merupakan salah satu komponen yang mampu memberikan pengaruh besar terhadap tercapainya tujuan organisasi. Hal tersebut tidak terlepas dari bagaimana upaya-upaya pimpinan mampu mengarahkan dan mengelola bawahan dalam pencapaian tujuan organisasi. Wexley \& Yukl (1977) dan Robbin \& Judge (2003) menjelaskan bahwa pada dasarnya proses kepemimpinan tidak terlepas dari usaha seseorang untuk mempengaruhi orang lain dalam mencapai suatu tujuan tertentu. Anderson et all (2005) menjelaskan "leadership is the process influencing the activities of an organized group toward goal achievement". Dari berbagai pengertian tersebut maka kata kunci pengaruh merupakan konsep yang penting yang dapat menggambarkan apa itu kepemimpinan.

Berbagai pendekatan teori kepemimpinan mengkaji bagaimana kita memandang perilaku kepemimpinan dari berbagai perspektif. Salah satu pendekatan yang digunakan dalam penelitian ini adalah pendekatan situasional yang dikembangkan oleh Hersey dan Blanchard.

Teori Kepemimpinan Situasional

Suatu pendekatan terhadap kepemimpinan yang menyatakan bahwa pemimpin memahami perilaku, sifat-sifat bawahannya dan situasi sebelum menggunakan suatu gaya kepemimpinan tertentu. Pendekatan ini mensyaratkan pemimpin untuk memiliki keterampilan dan kepekaan untuk memahami kondisi bawahan. Berbagai model kepemimpinan situasional akan mengkaitkan kepemimpinan sebagai hasil interaksi dari fungsi orientasi tugas, hubungan disertai kondisi bawahan, dalam hal ini kematangan. Lebih lanjut Fiedler (Robbin \& Judge, 2003) dalam model kontingensi menjelaskan bahwa efektivitas kepemimpinan akan tergantung dari orientasi perilaku yang mengarah pada tugas atau hubungan dengan dikaitkan dengan kondisi situasi yang menggambarkan derajat hubungan pimpinan dengan bawahan. Sedangkan Vroom \& Yetton mengulas bahwa kepemimpinan selain menggambarkan bagaimana perilaku yang ditampilkan juga bagaimana upaya melibatkan partisipasi bawahan dalam membuat keputusan. Sementara Robert House dalam path-goal theory menyatakan bahwa efektivitas kepemimpinan tergantung bagaimana pimpinan mampu menyediakan informasi, dukungan dan sumber-sumber yang diperlukan oleh bawahan dalam mencapai tujuan kerjanya melalui jalur-jalur yang jelas dan terarah.

Teori Kepemimpinan Situasional Hersey-Blanchard

Penekanan teori kepemimpinan situasional adalah pada bawahan khususnya terkait dengan bagaimana tingkat kematangan mereka. Oleh karenanya menurut Hersey \& Blanchard sangat penting bagi pemimpin untuk menilai secara tepat kondisi kematangan bawahanbawahannya sebelum menetapkan gaya kepemimpinan yang akan ditampilkan. Argumentasi pentingnya tingkat kematangan bawahan dalam menjamin efektivitas kepemimpinan dilandasi oleh pemikiran bahwa keberhasilan kerja bawahan akan dipengaruhi oleh seberapa besar kesesuaian perlakuan pimpinan dengan kondisi bawahan. Lebih lanjut Hersey \& Blanchard menjelaskan bahwa kematangan atau kesiapan didefinisikan sebagai kemampuan (ability) dan kemauan (willingness) dari 
bawahan untuk mengambil tanggung jawab pekerjaannya.

Kematangan atau kesiapan bawahan menurut Hersey-Blancard dan Blanchard ada hubungan yang jelas antara level kematangan orang-orang dan atau kelompok dengan jenis sumber kuasa yang memiliki kemungkinan paling tinggi untuk memunculkan kepatuhan pada orang-orang tersebut. Kepemimpinan situational memandang kematangan sebagai kemampuan dan kemauan orangorang atau kelompok untuk memikul tanggungjawab mengarahkan perilaku mereka sendiri dalam situasi tertentu. Maka, perlu ditekankan kembali bahwa kematangan merupakan konsep yang berkaitan dengan tugas tertentu dan bergantung pada hal-hal yang ingin dicapai pemimpin.

Lebih lanjut Yukl (2009) menjelaskan terkait dengan kepemimpinan situasional, bahwa seorang pemimpin harus memahami kematangan bawahannya sehingga tidak salah dalam menerapkan gaya kepemimpinan. Ada dua dimensi kematangan yang dimaksud adalah sebagai berikut:

1) Kematangan Pekerjaan

Dikaitkan dengan kemampuan untuk melakukan sesuatu. Hal ini berkaitan dengan pengetahuan dan keterampilan. Orang-orang yang memiliki kematangan pekerjaan yang tinggi dalam bidang tertentu memiliki pengetahuan, kemampuan, dan pengalaman untuk melaksanakan tugas-tugas tertentu tanpa arahan dari orang lain.

2) Kematangan Psikologis

Dikaitkan dengan kemauan atau motivasi untuk melakukan sesuatu. Hal ini erat kaitannya dengan rasa yakin dan keikatan. Orang-orang yang sangat matang secara psikologis dalam bidang kerjanya merasa bahwa tanggungjawab merupakan hal yang penting. Rasa yakin terhadap diri sendiri dan merasa dirinya mampu dalam aspek pekerjaan tertentu akan memerankan kekuatan yang besar dalam membangun komitmen kerja. Individu yang memiliki kematangan psikologis tidak membutuhkan dorongan ekstensif untuk mau melakukan hal-hal dalam bidang tersebut.

Berdasarkan kemampuan dan kemauan yang dijelaskan tersebut, maka kematangan bawahan dapat dikelompokkan menjadi empat level kematangan, seperti tertera pada tabel dibawah ini:

Tabel 1

Kontinum Tingkat Kematangan Bawahan

\begin{tabular}{cccc}
\hline TINGGI & \multicolumn{2}{c}{ SEDANG } & RENDAH \\
\hline M4 & M3 & M2 & M1 \\
& $\begin{array}{c}\text { Sedang - } \\
\text { tinggi }\end{array}$ & $\begin{array}{c}\text { Rendah - } \\
\text { Sedang }\end{array}$ & \\
\hline Mampu & Mampu & Tidak & Tidak \\
dan mau & tetapi & mampu & mampu \\
atau & tidak mau & tapi mau & dan tidak \\
percaya & atau tidak & atau & mau atau \\
diri & percaya & percaya & tidak \\
& diri & diri & percaya \\
& & & diri \\
\hline
\end{tabular}

Indikator dari kesiapan setiap level tersebut adalah sebagai berikut:

1) Dalam Kematangan Level 1 (M1), bawahan tidak mampu dan kurang komitmen dan motivasi untuk melaksanakan tugasnya atau dapat juga bawahan tidak mampu dan merasa tidak percaya diri untuk melaksanakan tugasnya. Indikator M1 atau tak mampu dan tidak mau antara lain adalah:

- Tidak melakukan tugas pada level yang dapat diterima

- Terintimidasi oleh tugasnya

- Tidak jelas mengenai arah tugas

- Penundaan pelaksanaan tugas

- Mengajukan sejumlah pertanyaan mengenai tugas

- Menghindari tugas

- Menjadi defensif atau tidak enak untuk melaksanakan tugas.

2) Dalam Kematangan Level 2 (M2), bawahan tidak mampu akan tetapi mempunyai kemauan untuk melaksanakan tugas. Bawahan kurang kemam- 
puannya akan tetapi termotivasi untuk berupaya melaksanakan tugasnya. Atau bawahan tidak mampu tapi punya percaya diri untuk melaksanakan tugasnya sepanjang pemimpin berada di dekatnya untuk memberikan panduan. Indikatornya adalah sebagai berikut:

- Tertarik dan responsif

- Menunjukkan kemampuan sedang

- Mau menerima masukan

- Penuh perhatian

- Antusiastik

- Mau melaksanakan tugas baru tanpa pengalaman.

3) Dalam Kematangan Level 3 (M3), bawahan mempunyai kemampuan akan tetapi tidak mempunyai kemauan untuk menggunakannya dalam melaksanakan tugas. Dapat juga bawahan mempunyai kemampuan akan tetapi tidak percaya diri untuk melaksanakan tugasnya. Indikator kesiapan ini adalah sebagai berikut:

- Telah menunjukkan pengetahuan dan kemampuan

- Tampak ragu-ragu untuk menyelesaikan atau mengambil langkah berikutnya dalam melaksanakan tugas

- Kelihatannya takut, kaget dan bingung

- Tampak masa bodo untuk melaksanakan tugas sendiri

- Sering meminta umpan balik.

4) Dalam Kematangan Level 4 (M4), bawahan mempunyai kemampuan dan kemauan untuk melaksanakan tugas. Atau mungkin juga bawahan mempunyai kemampuan dan mempunyai percaya diri untuk melaksanakan tugasnya. Indikator dari kesiapan ini adalah:

- Membuat atasan selalu terinformasi tentang kemajuan pelaksanaan tugas

- Mempergunakan sumber secara efisien

- Bertanggungjawab dan berorientasi pada hasil

- Dapat melaksanakan tugas secara independent
- Berbagi berita baik dan buruk

- Membuat keputusan yang efektif mengenai tugas

- Melaksanakan standar tinggi

- Berbagi ide kreatif

- Menyelesaikan tugas tepat waktu atau lebih cepat

Mengacu pada derajat kematangan

bawahan tersebut, Hersey-Blanchard menggunakan studi Ohio State untuk mengembangkan 4 (empat) gaya kepemimpinan yaitu sbb :

1) Telling

Tugas tinggi artinya banyak instruksiinstruksi yang perlu disampaikan mengingat bawahan baru menghadapi pekerjaan dan situasi baru. Hubungan rendah artinya pada tahap ini pimpinan belum banyak memberikan motivasi yang bersifat sebagai dukungan, karena bawahan belum siap karena memerlukan struktur kerja yang jelas sehingga kontrol kuat masih diperlukan.

2) Selling

Penetapan tugas-tugas tinggi disertai petunjuk yang terarah, bawahan mulai belajar mengenai tugasnya, perhatian dan tugas tetap pentinng karena mereka belum dapat bekerja tanpa struktur, namun dukungan psikologis tidak terlalu penting dilakukan karena bawahan pada dasarnya telah memiliki kesediaan secara psikologis yang kuat.

3) Paticipating

Bawahan mempunyai kemampuan lebih besar dibading kesediaan psikologisnya sehingga pemimpin tidak memerlukan pengarahan akan kemampuan yang harus dilakukan karena pada dasarnya sudah dimiliki bawahan. Namun dengan kesediaan psikologis yang masih rendah, pimpinan lebih menekankan untuk membangun komunikasi dua arah dan dukungan psikologis dalam membangun partisipasi bawahan dalam proses kerjanya. Upaya ini dilakukan untuk memunculkan ataupun meningkatkan motivasi bawahan lebih kuat lagi. 


\section{4) Delegating}

Bawahan sudah lebih percaya diri, dapat mengarahkan sendiri dan berpengalaman, tidak lagi mengharapkan pengarahan dari pimpinan, mereka sudah mandiri. Yang dilakukan pimpinan hanya sebatas mengevaluasi kinerja serta meminta pertanggungjawaban atas apa yang telah dilakukan bawahan.

Berdasarkan acuan dari katagori kematangan dikaitkan dengan gaya kepemimpinan maka dapat digambarkan matriks kepemimpinan situasional sebagai hal di bawah ini :

\section{Tabel 2}

Matriks Gaya Kepemimpinan dengan Kematangan Bawahan

\begin{tabular}{lcccc}
\hline $\begin{array}{l}\text { Gaya } \\
\text { Kepemim- } \\
\text { pinan }\end{array}$ & Telling & $\begin{array}{c}\text { Selling } \\
\text { Participa- } \\
\text { ting }\end{array}$ & Delegating \\
\hline $\begin{array}{l}\text { Tingkat } \\
\text { Kematanga } \\
\text { n Bawahan }\end{array}$ & M1 & M2 & M3 & M4 \\
\hline
\end{tabular}

Dengan demikian melalui pendekatan situasional, dapat disimpulkan bahwa tidak ada satu gaya kepemimpinan yang dianggap paling baik karena efektivitasnya akan tergantung pada siapa bawahan yang dihadapinya.

\section{METODE PENELITIAN}

Rancangan penelitian yang digunakan adalah deskriptif yaitu suatu rancangan yang bertujuan untuk membuat deskripsi, gambaran atau lukisan secara sistematis, faktual dan akurat mengenai karakteristik, fakta-fakta, sifat-sifat serta hubungan antar fenomena secara apa adanya (Arikunto, 2009). Adapun variabel penelitian yang diteliti adalah gaya kepemimpinan, yakni pola perilaku pemimpin dalam mempengaruhi bawahan yang dipersepsi oleh bawahan. Mengingat pendekatan teori kepemimpinan yang digunakan adalah situasional, maka kematangan bawahanpun menjadi variabel yang perlu diukur.
Populasi penelitian adalah seluruh staf operasional berjumlah 22 orang yang kedudukannya berada langsung di bawah kendali manajer operasional. Alat ukur yang digunakan berupa angket skala psikologis (Saifudin Azwar, 2000) yang mengukur bagaimana gaya kepemimpinan atasan yang dipersepsi bawahan dan tingkat kematangan bawahan dengan mengacu pada teori Hersey \& Blanchard (Robbin \& Judge, 2007) dengan terlebih dahulu dilakukan uji validitas dan reliabilitas. Pengolahan data dilakukan dengan menggunakan teknik statistik persentase.

\section{HASIL DAN PEMBAHASAN}

Dari hasil pengukuran diperoleh gambaran mengenai tingkat kematangan staf operasional PT Bank "X" Cabang Pamanukan sbb :

Tabel 3

Jumlah Responden Berdasarkan Tingkat Kematangan

\begin{tabular}{cccc}
\hline Kelas & Tingkat Kematangan & Frek & Prosentase \\
\hline MI & Rendah & 3 & $13,64 \%$ \\
M2 & Rendah menuju Sedang & 4 & $18,18 \%$ \\
M3 & Sedang menuju Tinggi & 6 & $27,27 \%$ \\
M4 & Tinggi & 9 & $40,91 \%$ \\
& Jumlah & 22 & $100,00 \%$ \\
\hline
\end{tabular}

Dari gambaran tersebut dapat disimpulkan bahwa 15 orang $(68,18 \%)$ bawahan telah memiliki kematangan pada tingkat yang sedang menuju tinggi dan tinggi. Artinya dari 15 orang tersebut, mereka telah memiliki kemampuan dan keahlian untuk menyelesaikan tugastugasnya namun 6 orang $(27,27 \%)$ diantaranya masih memiliki kematangan psikologis, dalam hal ini kemauan yang rendah. Sementara 7 orang $(31,82 \%)$ bawahan masih memiliki kemampuan kerja yang rendah dan rendah menuju sedang, meski $4(18,18 \%)$ orang diantaranya telah memiliki kemauan kerja yang tinggi. 


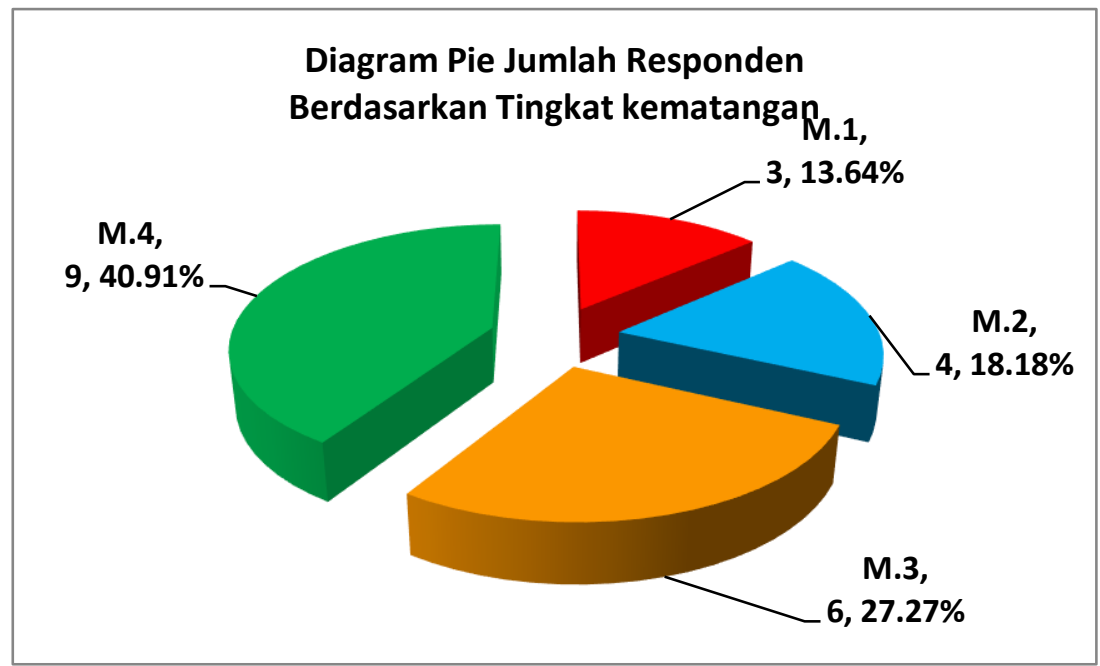

Tabel 4

Matriks Gaya Kepemimpinan dengan Kematangan Bawahan

\begin{tabular}{|c|c|c|c|c|c|c|c|c|}
\hline \multirow{3}{*}{$\begin{array}{c}\text { Gaya } \\
\text { Kepemimpinan }\end{array}$} & \multicolumn{8}{|c|}{ Kematangan Bawahan } \\
\hline & \multicolumn{2}{|c|}{ M1 } & \multicolumn{2}{|c|}{ M2 } & \multicolumn{2}{|c|}{ M3 } & \multicolumn{2}{|c|}{ M4 } \\
\hline & Frek & $\%$ & Frek & $\%$ & Frek & $\%$ & Frek & $\%$ \\
\hline Telling & & & & & & & 9 & $40,91 \%$ \\
\hline Selling & & & & & 6 & $27,27 \%$ & & \\
\hline Participating & & & 4 & $18,18 \%$ & & & & \\
\hline Delegating & 3 & $13,64 \%$ & & & & & & \\
\hline
\end{tabular}

Hasil pengukuran matriks gaya kepemimpinan dan kematangan bawahan tercantum dalam tabel diatas :

Berdasarkan gambaran data pada tabel 4 dapat disimpulkan bahwa pada semua katagori tingkat kematangan yang dimiliki bawahan, pada umumnya mempersepsi gaya kepemimpinan kurang sesuai. $40,91 \%$ bawahan yang memiliki tingkat kematangan tinggi mempersepsi gaya kepemimpinan manajer operasional sebagai gaya telling, $27,26 \%$ bawahan yang memiliki tingkat kematangan sedang menuju tinggi mempersepsi gaya kepemimpinan manajer operasional sebagai gaya selling, $18,18 \%$ bawahan yang memiliki tingkat kematangan rendah menuju sedang mempersepsi gaya kepemimpinan manajer operasional sebagai gaya participating dan 13,64\% bawahan dengan tingkat kematangan rendah mempersepsi gaya kepemimpinan atasan sebagai gaya delegating.

Dari gambaran data tersebut tergambar bahwa pimpinan unit operasional PT Bank "X" Cabang

Pamanukan dalam memerankan peran kepemimpinannya tidak mempertimbangkan kondisi bawahan. Secara teoretis, ketidaksesuaian gaya kepemimpinan yang digunakan dengan kondisi bawahan dapat menimbulkan pengaruh terhadap efektivitas prosesproses kepemimpinan yang dijalankan. Bila dikaitkan dengan ukuran efektivitas kepemimpinan, maka dapat dipahami mengapa tingkah laku bawahan tidak terarahkan pada proses pencapaian tujuan organisasi secara optimal. Pembahasan pada setiap katagori akan dipaparkan secara terpisah di bawah ini :

1. Kelompok 40,91\% (9 orang) bawahan yang memiliki tingkat kematangan 
tinggi mempersepsi gaya kepemimpinan atasan sebagai gaya telling.

Bawahan yang memiliki tingkat kematangan tinggi atau digolongkan ke dalam M4 adalah bawahan yang telah memiliki kemampuan memadai dalam menjalankan tugas-tugasnya disertai ketrampilan yang telah dikuasainya. Hal ini biasanya berkaitan kondisi kerja yang dihadapi, dimana karyawan tersebut mempunyai pengalaman pada tugas, dan nyaman dengan kemampuan mereka sendiri untuk melakukannya serta menyelesaikan pekerjaan dengan baik, merekapun sudah diberikan pelatihan softskill, dan terdapat kebijakan perusahaan untuk mengikut sertakan karyawan mengikuti pelatihan rollplay di Cabang untuk ujian product knowledge. Artinya, mereka mampu dan bersedia untuk tidak hanya melakukan tugas, tetapi juga mengambil tanggung jawab secara totalitas. Data lain terkait dengan hasil penilaian kerja subyek pada kelompok ini umumnya berada pada katagori baik menguatkan hasil pengukuran tersebut sehingga mereka layak digambarkan sebagai pegawai yang memiliki kemampuan memadai. Di sisi lain bawahan memaknakan pimpinannya memperlakukan mereka dengan gaya kepemimpinan telling, dimana awal perhatian pimpinan pada tugas sangat tinggi, bawahan diberi instruksi yang jelas dan masih dibiasakan dengan peraturan, struktur dan prosedur kerja. Hal tersebut menciptakan persepsi yang negatif terhadap kepemimpinan, karena karyawan sebagai bawahan merasa bahwa ia tidak diberi kesempatan untuk menerapkan dan menggunakan pengetahuan serta keterampilan yang dimilikinya. Hersey \& Blanchard menjelaskan gaya kepemimpinan telling memiliki ciri karakteristik dengan komunikasi satu arah, pemimpin memberitahu individu atau kelompok soal apa, bagaimana, mengapa, kapan dan dimana sebuah pekerjaan dilaksanakan. Pemimpin selalu memberikan instruksi yang jelas, arahan yang rinci, serta mengawasi pekerjaan secara langsung dan ketika gaya tersebut diterapkan pada karyawan dengan kematangan tinggi maka persepsi bawahan terhadap atasan dapat menjadi negatif. Bagi karyawan yang memiliki kematangan kerja tinggi akan membutuhkan pengakuan atas aktualisasi kemampuan dan kesiapan psikologis yang dimilikinya melalui pemberian tanggung jawab yang lebih besar dan terlibat dalam proses pengambilan keputusan yang terkait dengan lingkup kerjannya secara mandiri.

2. Kelompok $27,27 \%$ (6 orang) bawahan yang memiliki tingkat kematangan sedang menuju tinggi mempersepsi gaya kepemimpinan atasan sebagai gaya selling.

Bawahan dengan tingkat kematangan pada level M3 tersebut diatas sebenarnya mampu untuk melaksanakan tugas tetapi karena sesuatu hal menjadi tidak yakin akan keberhasilan sehingga tugas tersebut tidak dilaksanakan dengan optimal. Bawahan dengan tingkat kematangan diatas dibina dengan gaya kepemimpinan selling tentunya kurang tepat mengingat persoalan yang dihadapi bawahan bukan pada persoalan kemampuan teknis pekerjaan namun lebih pada kesiapan psikologis yakni kemauan yang rendah yang dapat bersumber dari motivasi diri rendah atau kurang percaya diri. Oleh karenanya ketika memaknakan perlakuan pemimpin sebagai gaya selling akan ditangkap sebagai upaya yang kurang tepat sasaran. Hersey \& Blanchard menjelaskan indikator bawahan dengan katagori M3 diantaranya memiliki ketrampilan dan pengetahuan kerja yang baik namun masih diliputi raguragu atau mungkin bersikap masa bodo terhadap tugasnya sehingga komitmen penyelesaian tugasnya diragukan. Pada situasi ini yang dibutuhkan bukan lagi 
arahan tugas yang terstruktur, namun lebih pada membangun dukungan psikologis dengan melibatkan bawahan secara partisipatif agar bawahan memiliki kemauan atau membangun rasa percaya diri. Pada bawahan level M3 lebih tepat digunakan gaya kepemimpinan partisipatif yang dicirikan melalui proses komunikasi terbuka dua arah untuk membangun dukungan psikologis ataupun motivasi diri karyawan. Sementara gaya kepemimpinan selling lebih diwarnai oleh arahan tugas dan cara-cara suatu pekerjaan harus diselesaikan melalui petunjuk dan SOP yang sudah ada dengan mencoba bersama-sama membantu memetakan kemampuan apa yang harus dibentuk.

3. Kelompok 18,18\% (4 orang) bawahan yang memiliki tingkat kematangan rendah menuju sedang mempersepsi gaya kepemimpinan atasan sebagai gaya participating.

Kelompok bawahan pada kategori kematangan level M2 adalah karyawan yang memiliki kesiapan secara psikologis untuk bekerja namun belum memiliki kemampuan kerja yang memadai dalam bidang kerjanya. Pada tingkat kematangan rendah menuju sedang ini, karyawan sebagai bawahan tidak mampu melaksanakan tugas namun mau bertanggung jawab. Dengan kata lain, walaupun kemampuan dalam melaksanakan tugasnya rendah tetapi memiliki rasa tanggung jawab sehingga ada upaya berprestasi. Karyawan tersebut merasa yakin akan pentingnya tugas dan tahu pasti tujuan yang ingin dicapai namun belum disertai kemampuan yang memadai. Ada beberapa hal yang menjadi penyebab, diantaranya belum berpengalaman, belum mendapat pelatihan dan pendidikan tetapi memiliki motivasi tinggi, atau karyawan yang mendukuki jabatan baru dimana punya semangat tinggi tetapi ia belum memahami apa yang harus dilakukannya. Pada kondisi bawahan seperti ini, yang dibutuhkan adalah petunjuk kerja dan coaching mengenai apa yang harus dibangun, diberikan pelatihan dan ketrampilan yang akan menunjang kelancaran tugastugasnya. Sementara dukungan psikologis dan komunikasi dua arah untuk membangun motivasi tidak menjadi hal yang utama mengingat aspek tersebut sudah dimiliki oleh bawahan. Oleh karenanya bika dikaitkan dengan hasil penelitian, justru sebaliknya, kelompok bawahan pada level ini mempersepsi gaya kepemimpinan atasan sebagai gaya participating yang lebih menekannya pada upaya membangun dukungan psikologis dengan melibatkan bawahan secara partisipatif untuk membangun kesediaan psikologis yang sesungguhnya telah mereka miliki.

4. Kelompok 13,64\% (3 orang) bawahan yang memiliki kematangan rendah mempersepsi gaya kepemimpinan atasan sebagai gaya delegating.

Bawahan pada kelompok kematangan level M1 adalah tidak mampu dan tidak mau atau tidak percaya diri. Hersey \& Blanchard menjelaskan indikator dari bawahan pada level ini adalah diantaranya menunda pekerjaan, menghindar, bekerja tanpa arah yang jelas karena tidak memahami apa yang harus dilakukan. Data penunjang yang diperoleh bahwa kelompok karyawan ini memang tergolong karyawan yang memiliki penilaian kerja yang tergolong belum memadai. Meski telah mendapatkan pelatihan namun dirasakan bahwa apa yang diperoleh belum cukup mendukung kemampuannya dalam menjalankan proses kerjanya secara berkembang. Kesediaan yang rendah untuk meningkatkan diri menjadikan kemampuan yang dimilikinya minimal dan digunakan sebatas memenuhi kewajiban sehingga produktivitas yang dihasilkannyapun baru mencapai standart minimal. Oleh karena diperlukan acuan kerja yang jelas disertai tun- 
tutan target yang dilakukan oleh eksternal disertai dorongan dan dukungan psikologis yang mampu membangun motivasi diri yang lebih kuat dengan diikuti peran kontrol yang tinggi pula. Perlakuan-perlakuan tersebut akan diperoleh melalui gaya kepemimpinan yang bersifat telling bukan gaya delegating.

\section{SIMPULAN DAN SARAN}

Dari 22 orang karyawan unit operasional PT Bank " $X$ " Cabang Pamanukan, tidak ada satupun yang mempersepsi gaya kepemimpinan atasan yang sejalan dengan katagori level kematangan yang dimilikinya dengan rincian $\mathrm{sbb}$ :

1. $40,91 \%$ karyawan staf operasional dengan tingkat kematangan tinggi mempersepsi gaya kepemimpinan atasannya sebagai gaya telling.

2. $27,27 \%$ karyawan staf operasional dengan tingkat kematangan sedang menuju tinggi mempersepsi gaya kepemimpinan atasannya sebagai gaya selling.

3. $18,18 \%$ karyawan staf operasional dengan tingkat kematangan rendah menuju sedang mempersepsi gaya kepemimpinan atasannya sebagai gaya participating.

4. $13,64 \%$ karyawan staf operasional dengan tingkat kematangan rendah mempersepsi gaya kepemimpinan atasannya sebagai gaya delegating.

Saran terkait dengan simpulan tersebut :

1. Melakukan intervensi kepada pimpinan dengan melakukan pelatihan pengembangan kepemimpinan situasional sehingga dapat melakukan tindakan kepemimpinan yang disesuaikan kondisi bawahan.
2. Meningkatkan kematangan kerja bawahan yang masih berada pada level M1, M2 dan M3 melalui pola-pola intervensi yang tepat.

3. Melanjutkan penelitian gaya kepemimpinan situasional dengan mengkaitkannya terhadap variabel lain, a.l motivasi kerja atau produktivitas kerja.

\section{DAFTAR PUSTAKA}

Anderson et all, 2005. Handbook of Industrial, Work and Organizational Psychology. London, Sage Publications.

Arikunto, Suharsimi,. 2009. Manajemen

Penelitian. Jakarta. PT Rineka Cipta.

As'ad, Mochammad. 2003. Psikologi Industri. Edisi Keempat. Yogyakarta. Liberty Offset.

Azwar, Saifudin,. 2000. Penyusunan Skala Psikologi. Yogyakarta. Pustaka Pelajar.

Gary Yukl. 2009. Kepemimpinan dalam Organisasi. Jakarta.PT. Macan Jaya Cemerlang

Milton, Charles. R,. 1981. Human Bahavior in Organization. New Jersey. Prencite-Hall.

Robbins, S. P., 2003, Perilaku Organisasi, Jilid 1, PT Indeks, Gramedia Group, Jakarta.

Siegel, S., 1990, Statistik Non Parametrik untuk Ilmu-ilmu Sosial, PT Gramedia, Jakarta.

Wexley, Keneth N. \& Yukl, Gary. A,. 1977. Organizational Behavior and Personnel Psychology. Fourth Edition. New York. McGraw-Hill Book Company. 
